\title{
ANIMALES Y 'GENTILES' SEDUCTORES EN LOS RELATOS ANDINOS
}

\author{
Néstor Godofredo TAIPE CAMPOS \\ Programa de Desarrollo Alternativo en el Alto Huallaga (Perú) \\ ngtaipe@yahoo.com
}

\begin{abstract}
ANIMALS AND ‘GENTILES' SEDUCTIVE IN THE ANDEAN STORIES
Resumen: En este artículo, presento 20 cuentos quechuas (traducidos al español) que fueron registrados en el nororiente de la provincia de Tayacaja (Huancavelica, Perú), alguno de los cuales presenta reminiscencias de relatos míticos. Los seductores registrados son el perro, el matamico andino, la culebra, el murciélago, la perdiz, el ratón, el gorrión y el "gentil". Todos seducen a las mujeres jóvenes. Sólo la perdiz seduce a un varón joven. En este trabajo estudiaré cómo influye el contexto en la construcción de los relatos, cómo se construyen las analogías, la simbología y la configuración dinámica de las alteridades implícitas.

Abstract: In this article, I present 20 stories Quechua (translated into Spanish) that were recorded in the northeast of the province Tayacaja (Huancavelica, Peru), some of which is reminiscent of mythical stories. Seducers are registered dog, the Andean matamico, the snake, the bat, the partridge, the mouse, the sparrow and the "gentile". All seduce young women. Only Partridge seduces a young male. In this paper, I will study how the context influences in the construction of the stories, how analogies, symbolism and dynamic configuration of implied otherness are built.
\end{abstract}

Palabras clave: Relatos orales. Andino. Seducción. Analogía. Simbología. Alteridades Oral stories. Andean. Seduction. Analogy. Symbolism. Otherness 


\section{Introducción}

En ciertos relatos orales andinos es impresionante el motivo de la seducción de los animales y del "gentil" a las mujeres jóvenes y a los muchachos. Un recuento de la literatura andina y amazónica presenta este mismo motivo con ciertas variaciones e involucramiento a seres míticos. Así, el oso ${ }^{1}$, el escarabajo estercolero, el zorro ${ }^{2}$, el delfín ${ }^{3}$ y el cóndor ${ }^{4}$ son seductores de muchachas. En cambio, la osa, la paloma y la "sirena" son seductoras de varones $^{6}$. Relacionado con lo anterior, hay amuletos de origen animal asociados con el mitocreencia de facilitar la seducción de las muchachas por el varón portador de la punta de la cola del zorro o la cabeza de una culebra. En fin, los relatos con esta trama son numerosos. ${ }^{7}$

Las deidades son igualmente protagonistas de diversas seducciones. El dios creador andino Cuniraya Viracocha, transformado en un pájaro, sedujo a la diosa Cavillaca (Ávila, 1975; Taylor, 2008). Los dioses montañas (Apus o Wamanis) y las lagunas seducen tanto a mujeres como a varones (Taipe, 1991; Fuenzalida, 1980). El Wari, adoptando formas femeninas, puede seducir a los varones. En tiempos míticos el Sol seducía a las muchachas y la Luna a los muchachos (Taipe y Orrego, 1997a). Los manantiales pueden adoptar formas masculinas y femeninas, entonces se emparejan con mujeres o varones y hasta pueden reproducirse (BDA, 2002).

Claude Lévi-Strauss presenta una gran riqueza de mitos semejantes a los relatos registrados en Tayacaja. En Mitológicas 1 (2002) y 2 (1972) la trama de la heroína y la serpiente está relacionada con el origen del "[achiote], el árbol de resina, el tabaco, el maíz y el algodón [...]" que surgen de las cenizas de la serpiente muerta e incinerada por los hermanos de la heroína (2002: 107); es origen de la vida breve de los humanos, origen de las estrellas y del arco iris. Hay mitos sobre mujeres casadas con murciélagos que están relacionados con el origen de las pinturas rupestres, ciertos bienes culturales como las hachas y los instrumentos musicales. En la mitología Tsimshian, el búho rapta y se reproduce con una joven (Lévi-Strauss, 2004). También hay otros seductores como la nutria, el tapir, el jaguar, el caimán, etc.

Por mi parte, durante un trabajo de campo realizado por el norte de Tayacaja (Huancavelica, Perú), he registrado 20 cuentos quechuas que los traduje al español, algunos de los cuales presenta reminiscencias de mitos. Los seductores que he registrado son el perro, el aqchi, la culebra, el murciélago, la perdiz, el ratón, el gorrión y el "gentil". Todos, menos la perdiz, seducen a las muchachas. La perdiz seduce a un joven. En este artículo estudiaré cómo influye el contexto en la construcción de los relatos, cómo se construyen las analogías, la simbología y la configuración dinámica de las alteridades implícitas. Se toma un relato de cada grupo como referente para el análisis y los demás son presentados en el anexo.

\section{Influencia del contexto socio-ecológico en los relatos}

La trama común de los relatos es la seducción de las muchachas y muchachos jóvenes por los animales y el "gentil". Los relatos, aun aquellos con altos componentes fantasiosos, no son construidos sobre la nada, sino son producidos tomando elementos de los contextos específicos, es decir, del complejo de factores y circunstancias físicas, culturales, sociales, psicológicas, temporales y espaciales.

1 Ver Morote, 1988; Weber, 1987; y Taylor, 1997.

2 Ver Landeo, 2014.

3 Ver Kulak, 2006.

4 Ver Saavedra, 2011; Moya y Jara, 2009; y BDA, 2002.

5 Ver Landeo, 2014.

6 Ver Báez-Jorge, 1992; Millones y Tomoeda, 2004.

$7 \mathrm{Mi}$ agradecimiento a Rommel Plasencia Soto por sus comentarios al borrador de este artículo. 
El escenario donde registré los relatos está constituido por una geografía abrupta, cuyas altitudes van desde los 1,060 msnm hasta los 4,300 $\mathrm{msnm}$, con una flora y fauna diversa. La agricultura y el pastoreo tienen cierta "especialización" adaptada a cada altitud. En las partes bajas hay plantaciones de frutas, cultivan frijol, panamito y maíz. En las partes altas hay cultivos de tubérculos andinos. Con respecto a la actividad pecuaria, los porcinos, cuyes y aves de corral son criados en casa. El ovino y caprino apacientan cuidadas por las pastoras con ayuda de algunos canes en las partes altas de la montaña; si los pastizales están muy lejos, se quedan en las estancias cuidado a los animales. La crianza de équidos y vacunos es extensiva. Los animales viven, crecen y se reproducen a su antojo en el monte. Los campesinos los juntan esporádicamente para darles sal y dejarlos nuevamente en los "echaderos". Sólo cuando tienen necesidad de utilizar a las bestias de carga o cuando las vacas se reprodujeron las traen a casa para aprovechar de la leche. Todos los campesinos tienen acceso a parcelas y pastizales en las partes bajas y altas del territorio de sus comunidades.

A principios de los '80 para llegar a Salcahuasi y alrededores se tenía que viajar desde la ciudad de Huancayo a lo largo de más de un centenar de kilómetros por una trocha carrozable. Sólo entraban camiones medianos. Saliendo por la mañana se llegaba a punta de carretera en San Isidro de Acobamba (en el distrito de San Marcos de Rocchac) como a las cuatro de la tarde (ahora este recorrido se hace en una camioneta apenas en dos horas y media). De Huancayo se tiene que subir hasta alcanzar un abra en la Cordillera Central (4,400 msnm) y luego bajar hacia las lagunas Aquile (laguna macho) y Cochapata (laguna hembra), a partir de ésta se continúa por la rivera del rio Wari, pasando por el Centro Poblado Wari y Trancapampa hasta San Isidro de Acobamba, donde había una feria en la que se tenía que comer algo y empezar a recorrer un camino de herradura, se llegaba a los fundos Maparumi y Matibamba, luego se pasaba por Manchay y Potrero, lugares donde habían unas tiendecitas que vendían aguardiente, gaseosas y cerveza. Para llegar a la comunidad campesina La Loma se caminaba unas 6 horas, a Salcahuasi, San Antonio y Pongollo unas 7 horas. Generalmente los caminantes llegaban a su destino como a la media noche. Ahora desde Huancayo a todos estos lugares se llega con una camioneta en unas 4 horas y media.

Durante los ' 80 , por los meses de junio y julio, los campesinos de la zona llevaban sus productos para venderlos en la feria de San Isidro de Acobamba (luego esta feria fue avanzando hasta Manchay, Loma Baja, San Antonio, Chiquiac... en fin). Los productos a venderse (frijol, panamito, maíz, papa...) eran trasladados en acémilas. Era fácil ver recuas de 60 o 70 bestias. Cada campesino viajero llevaba al cinto un puñal, una piska (bolsa) con hojas de coca y media botella de aguardiente. Después de vender hacían algunas compras y retornaban cuando el sol iba cayendo para viajar más aliviados aprovechando la sombra de la noche. Ahora a casi todos los pueblos llega una trocha carrozable, por tanto, ya es más fácil vender sus productos y comprar los artículos necesarios.

Desde antaño hubo jóvenes que emigraron hacía las ciudades. Pero ahora, con las carreteras, el flujo migratorio es más intenso. Muchos campesinos de estos lugares tienen sus casas en las ciudades. Los jóvenes prefieren emigrar a estas últimas o la selva. Con ellos viajan su idioma, sus gustos (gastronómicos, auditivos, olfativos y cromáticos), sus costumbres, su memoria y, entre ésta, sus relatos. Algunos de ellos se mantendrán, otros cambiarán o pasarán al olvido. Como es natural, las generaciones nuevas ya no reproducen la cultura del cual proceden sus padres.

Pero la gente no sólo sale sino también ingresa. Entre éstos están los docentes de las instituciones educativas, los trabajadores de salud, algunos empleados municipales, los comerciantes (que se establecen en las ferias y los ambulantes que compran ganado), los transportistas, el cura que, igual que los músicos, viene muy esporádicamente sólo para las fiestas patronales y, durante el periodo al que aludimos, también eran considerados como los "otros" los miembros de PCP-SL, del MRTA y los soldados del ejército. Para los '80 del siglo pasado ya no había haciendas, la mayoría había sido expropiada por la Reforma Agra- 
ria, trayendo consigo la eliminación de la alteridad radical entre "indio"/"misti" (indígena de hacienda/hacendado e indígena de comunidad/hacendado). La oposición ha cambiado de actores, ahora se entabla entre campesinos y grupos de poder local ejercido por algún profesional de procedencia campesina o citadina y algunos comerciantes instruidos y relativamente acomodados.

A principios de los ' 80 en estos pueblos no había servicio de electricidad, ahora si los tienen, además ya poseen telefonía comunitaria fija y telefonía móvil. Estos hechos junto con las carreteras han modificado los estilos de vida de antaño. La telefonía ha eliminado el espacio y el tiempo. Si antes se usaban lámparas de kerosene ahora tienen electricidad con la que pueden estudiar, escuchar radio y ver TV y estar así enterados de lo que sucede en otros lugares del país y el mundo.

La carretera avanzó hacia los distritos de Surcubamba, Huachocolpa y Tintay Puncu. Durante la primera mitad de la década del 80 del siglo pasado, aún pude ser testigo de cómo los comuneros de más un centenar de comunidades se turnaban para trabajar en la construcción de la carretera, iban con sus propias herramientas y preparaban sus propios alimentos. Esto hace recordar a Arguedas (1983) que narró que los comuneros de Lucanas construyeron en 1926 la carretera de Puquio a Nazca sin apoyo del Gobierno; pero también hace rememorar a la Ley de conscripción vial (1920) (Castro Pozo, 1979) que obligaba a trabajar gratuitamente a los varones en la construcción de carreteras, en la reparación de caminos y obras anexas.

Por los '80 el gobierno subnacional apenas ponía un par de máquinas, combustible y los operadores, la mano de obra no calificada era comunera. Las políticas fueron cambiando, los presupuestos incrementaron. Ahora son el Gobierno Regional o el Ministerio de Transportes y Comunicaciones (con Provías Nacional) los que financian las construcciones de las carreteras departamentales y los caminos vecinales. Así, la carretera continuó avanzando también en dirección de Salcabamba a partir del cual se accede a la ciudad de Pampas (capital provincial). Los distritos San Marcos de Rocchac y Quishuar también tienen carreteras. Desde las capitales distritales, las carreteras continúan avanzando hacia los centros poblados y comunidades campesinas.

Quien recorre por las cordilleras de esta parte de Tayacaja, puede observar los cerros (muchos de los cuales son Apus o Wamanis -dioses montañas- locales y regionales), las lomas, las quebradas, los picos de las montañas, las abras y los nevados, sintiendo las caricias del viento frío de las punas; ver los ríos, los manantiales, las lagunas; las pastoras y las chozas de las estancias solitarias y alejadas de los centros poblados; escuchar los balidos o mugidos de los rebaños, los ladridos de los perros pastores; disfrutar del vuelo de los aqchis, los halcones, cernícalos y, con un poco de suerte, de cóndores; observar los campos de cultivos, la floración diversa de las papas; a veces el caminante se encuentra con algún zorro o experimenta sobresaltos cuando alguna perdiz sale volando con escandaloso graznido casi de los pies porque no lo pudo ver por tener sus plumajes del mismo color que el ichu. Bueno, de vez en cuando, uno puede tener un encontrón con alguna culebra y más raramente con algún puma. Pero también en diferentes puntos de este territorio hay restos de los antiguos asentamientos prehispánicos waris, de cuyos huesos y objetos temen los campesinos porque dicen que los pueden enfermar. Los cuentos que son materia de estudio surgen en este contexto.

El año 2014 hice un recorrido de Salcahuasi hacia Pampas y viceversa. Al subir de Salcahuasi hacia la cumbre de Churiaqasa y bajar en dirección de Palca (Salcabamba) tuve la sensación de estar en el "escenario" donde "acontecieron" dichas narraciones. Obvio que al observar el vuelo de las aves o cuando los aqchis te miran con curiosidad, cuando de pronto sale del monte algún toro con apariencia de gran bravura, cuando se aparecen algunos caballos que andan libremente por los cerros, realmente uno se siente intruso en estos territorios. En suma, la ecología, la cultura, la economía, la construcción de las otredades, el 
comportamiento de los animales y ciertas costumbres sociales se engranan en el imaginario para producir dichos relatos.

\section{Los seductores en los relatos}

¿Quiénes son los actantes? ¿Cómo se construyen las analogías entre seductores y humanos? ¿Cuál es la simbología de estos animales? Para contar con más elementos explicativos, en la exposición acudiré en ocasiones a relatos de otros contextos sociales y culturales, allí donde sea posible utilizaré los registros realizados por los cronistas y los resultados de las investigaciones arqueológicas.

\subsection{Los actantes}

Los actantes seductores en los relatos son el perro, el aqchi, la culebra, el murciélago, la perdiz, el ratón, el gorrión y el "gentil". Siete actantes son de connotación masculina, sólo la perdiz es de connotación femenina. Estos animales y los esqueletos de los "gentiles" son parte del hábitat de los campesinos y que entre éstos y aquellos existen diversas formas de relaciones, prestándose a objetivar las connotaciones masculinas y femeninas y las construcciones analógicas de los personajes, a través de los cuales se metaforizan las otredades sociales y culturales.

Los actantes humanos son las muchachas y los jóvenes campesinos. En algunos relatos intervienen los padres y otras personas de la comunidad ¿Por qué? Se puede pensar porque los jóvenes (hombres y mujeres) son neófitos sexualmente y porque que las actividades económicas los relaciona con los actantes seductores. La intervención de los padres y otras personas de la comunidad hacen evidente las otredades rechazadas o de quienes se debe temer y desconfiar.

La asociación entre humanos y animales está determinada por la ecología, la actividad económica y los hábitos de los actantes. Las muchachas pastoras están asociadas al perro por el pastoreo, el perro participa en el cuidado de los animales, cuando se beneficia a éstos, el perro es consumidor de algunos restos como las vísceras y los huesos; al aqchi por la actividad económica y por la ecología, el aqchi gusta remover las heces del ganado para buscar gusanos con los que se alimenta, pero al mismo tiempo, el pastoreo se realiza en el hábitat de esta ave; a la culebra porque hay la creencia que ésta gusta alimentarse de la leche vacuna, pero también el pastoreo se realiza en el hábitat de este reptil; el murciélago se relaciona con la mujer a través de la ganadería, se dice que el murciélago muerde a los animales por las noches, además durante la oscuridad, las casas y las chozas de las estancias reciben visitas del quiróptero.

Las estancias son unas chozas de paja o construcciones pequeñas con muros de piedra techadas con paja que permiten que las pastoras pernocten en el campo cuidando al rebaño. Las estancias generalmente están en zonas alejadas y aisladas de los poblados. Las pastoras viven allí acompañadas de sus perros. De ahí que sea explicable porqué los primeros encuentros sexuales de estas jóvenes ocurran en el campo.

El varón y la perdiz están asociados con la agricultura. Desde la siembra hasta la cosecha, la perdiz escarba los campos de cultivo en busca de los tubérculos. La perdiz se asocia también con la cocina, cuando sus huevos son hallados o cuando ella es capturada es consumida por la familia campesina.

Las muchachas, el ratón y el gorrión están relacionados con la agricultura. Las primeras son las que manipulan los alimentos, el ratón es consumidor de cereales tanto en el campo de cultivo como dentro de la casa, el gorrión ayuda en el proceso de polinización de las plantas de maíz pero es consumidor de cereales en el campo de cultivo.

Las muchachas y el "gentil" están relacionados por la ecología. Generalmente los restos arqueológico de los antiguos poblados están en las partes altas de las montañas, lugares 
donde las mujeres pastan al ganado.

\subsection{Las analogías}

Primero presentaré el texto correspondiente de los seductores y luego identificaré las analogías por el cual fueron construidos los actantes. Estos textos serán también los referentes para analizar la simbología, el tiempo, el espacio y el desenlace de los relatos.

El perro seductor ${ }^{8}$. A este grupo pertenecen los relatos $(\mathrm{R})$ 1, 2, 3 y 4. El R1 será el referente de análisis y los demás son presentados en el anexo.

R1: Narrado por Silvia Mendoza, 78 años de edad, natural de Pongollo, Salcahuasi, Tayacaja, registrado en 1987:

Cierta vez una chica estaba con un perro. El perro llegaba donde la muchacha sólo por las noches, iba vestido con un terno negro y corbata blanca. Cada noche el perro llevaba chicharrones a la muchacha.

Cierto día el perro dijo: "Estaré en un banquete, estaré detrás de aquel cerro, vendrás el día de mañana” - invitó a la chica.

Cuando la muchacha fue al lugar indicado al día siguiente, vio que muchos perros disputaban por la carne de un burro muerto.

“¿A qué hora vendrá?” -preguntándose iba esperando. Cuando estuvo a punto de retornar, un perro se le acercó trayendo una tremenda presa de carne de burro y, poniéndolo al lado de la muchacha, regresó al festín.

“ ¿Por qué este perro me trae esta carne sucia?”-pensaba. Después de esperar un rato, retornó a su casa.

Esa noche, el perro se presentó de nuevo y la muchacha le reclamó:

“Por qué no llegaste? Me engañaste. Te esperé toda la tarde”.

El perro contestó:

"Pero si estuve a tu lado".

"Mentiste. No estuviste allí. Sólo muchos perros se quitaban la carne de un burro muerto".

Después de la discusión durmieron juntos. Entonces el perro dijo:

"Mañana estaré en otro banquete, tú también vendrás".

Era época de fiesta. La muchacha le puso al joven unas amarraderas, una manta y una faja. Así se fue el muchacho. Entonces el perro en esa fiesta caminaba de un lado para otro luciendo una manta nueva, con unas amarraderas en sus tobillos y con una faja en la cintura. El perro juntaba todo el día a los huesos que dejaban los comensales.

La muchacha llegó a dicha fiesta por la tarde y vio que un perro caminaba con su manta, sus amarraderas y la faja.

La chica lloró de rabia: “ ¿Por qué hizo poner mi manta a un perro?”

El perro trajo al lado de la mujer a los huesos que en el día había juntado. La muchacha regresó encolerizada.

Esa noche nuevamente llegó el perro: “¿Por qué no has traído ese combinado (huesos)?”-diciendo pateó a la muchacha.

En reacción, la muchacha agarró un gran palo con el que golpeó incansablemente al joven. Entonces, el joven recobró su forma de perro. La muchacha recién se percató que había estado con perro.

Las analogías entre el perro seductor y el humano al que representa son construidas de la siguiente manera. Los colores del pelaje se convierten en colores de la vestimenta del

8 Perro (Canis lupus familiaris). En quechua le dicen allqo. 
seductor, entonces el perro se presenta ante la muchacha, cuando visita a la estancia por las noches, como un joven elegante, vistiendo un terno negro y corbata blanca. En esta descripción hay analogía entre el perro y el "misti" (el blanco), el "mestizo" y el "citadino" que visten diferente de los campesinos.

Cuando invita a la joven a asistir a una fiesta, el seductor aparece como perro con delantal, una faja, sujetadores de bastas y una manta que fueron tejidos y regalados por la joven. En este caso la analogía está construida entre el perro y el campesino agricultor.

La "fiesta" y el "convite" a la que es invitada la mujer es una reunión de canes que disputan la carne de algún équido u otro animal muerto. Cuando se trata de una fiesta de humanos, el perro junta huesos y le lleva a la muchacha. Uno de los relatos describe que el amante-perro le dice "sacaré de la fiesta comida para ti" (alzakamusaykym), este hecho es una analogía con la práctica del invitado de guardar parte de su comida o pedir otra porción al anfitrión para llevarlo a casa.

El aqchi seductor ${ }^{9}$. A este grupo pertenecen los relatos (R) 5, 6, 7, 8 y 9. El R5 será el referente de análisis y los demás son presentados en el anexo.

R5: Narrado por don Marcos Ramos, de 78 años de edad, natural de Pongollo, Salcahuasi, Tayacaja, registrado en 1988:

Cierta vez el aqchi engañó a una muchacha.

El aqchi llegaba a enamorar a la muchacha sólo por las noches. Llegaba convertido en un joven luciendo un terno negro, una corbata blanca y unos zapatos rojos.

En una ocasión, el "muchacho" dijo a la joven:

-Mañana me traerás la comida. Barbecharé detrás de aquel cerro. Traerás frituras de tripas -encargó.

La muchacha preparó la comida. Fritó tripitas. Cargando la comida llegó al lugar indicado por el joven. Vio a todas partes pero no encontró al joven. Sólo en la parte inferior de la quebrada, muchos aqchis estaban picoteando y escarbando las heces de las vacas. Después de haber estado viendo el espectáculo por mucho rato, sentándose en la parte alta esperó, "puede aparecer de cualquier lugar" -diciendo.

Cuando la chica se sentó encima de una piedra, algunas aves iban revoloteando encima de ella, y otras iban escarbando las heces de vacas.

La muchacha iba pensando "¿por qué las aves me rodean? Ella retornó a su casa enfurecida. "Me mintió" -diciendo.

Por la noche, el "muchacho" llegó y dijo:

-¿Por qué no me trajiste la comida que te encargué?

La muchacha respondió:

-No te encontré. Mentiste y me hiciste andar por todo el cerro llevando tu comida. Por aquel morro sólo vi muchas aves que estaban escarbando y picoteando las heces de las vacas. Tú no estuviste allí-dijo.

-Yo anduve por allí ¿acaso no estuve andando por tu lado? -dijo el muchacho.

La muchacha respondió:

-Entonces tú serás aqchi pues.

La muchacha recién meditó que habría estado con el aqchi, reaccionó con rabia y colgó al aqchi con una soga hasta darle muerte.

En tiempos antiguos dicen que no hubo jóvenes. Por tal razón los animales "engañaban" a las chicas.

9 Matamico Andino (Phalcoboenus megalopteru). En quechua le dicen aqchi. Pero también le dicen cariñosamente "El caballero". 
Los colores de las plumas y las patas del ave se convierten en colores de la vestimenta del seductor. El aqchi, cuando visita por las noches a la estancia, se presenta ante la muchacha como un joven elegante, vistiendo un terno negro, corbata blanca, medias blancas y botas rojas. Hay analogía entre el aqchi y el "misti" (el blanco), el "mestizo" y el "citadino" que viste diferente de los campesinos.

Cuando pide a la joven que lleve comida para los peones con los cuales barbechará la tierra, el aqchi pide que la chica le lleve "tallarines" y "tripitas fritas" que es la analogía de las lombrices de tierra. En todos los relatos, cuando la mujer llega al lugar indicado llevando la comida, observa que un grupo de aqchis ("los peones") voltean ("barbechaban") las heces de las vacas buscando gusanos.

Las prendas campesinas de los labradores como el delantal, los sujetadores de bastas, las fajas y mantas embellecen graciosamente a los relatos al presentar al perro y aqchi utilizando dichas prendas confeccionadas por la joven. En la vida real, son las mujeres las que tejen estas prendas y las obsequian al varón en el proceso de enamoramiento o durante la convivencia como prueba que ya está lista para el matrimonio.

Culebra seductora ${ }^{10}$. A este grupo pertenecen los relatos 10, 11, 12, 13 y 14. El R10 será el referente de análisis y los demás son presentados en el anexo.

R10: Relato de Silvia Mendoza de 72 años de edad, natural de Pongollo, Tayacaja, registrado en 1987:

Un hombre tenía dos hijas que ya estaban jóvenes.

Las muchachas eran amantes de una serpiente que vivía debajo del batán.

Una había dicho: "Joselito estará hambriento".

Las muchachas habían ordeñado a una vaca, luego en un mate grande depositaron leche junto al batán.

Pero dos muchachos estaban escuchando lo que decían las muchachas y estaban observando lo que hacían.

Éstos dijeron “¿Quién será ese José?” Entonces, de debajo del batán salió una inmensa serpiente.

Los muchachos, después de reaccionar de su asombro, dieron muerte a la serpiente: "Carajo, éste había sido José", diciendo.

Las muchachas lloraron la muerte de la serpiente. Por la noche dicen que la serpiente salía como un joven muy apuesto y dormía con las muchachas.

El padre de las muchachas colgó a éstas con una soga, entonces del sexo de las muchachas salieron muchas serpientes pequeñas. Desde entonces pues existen estas puercas sabandijas.

La culebra se presenta ante la muchacha por las noches como un joven apuesto. El padre Lira registró en el Alto Urubamba que la serpiente se presentaba ante la muchacha como joven muy fino y muy delgado. "El mozo caminaba y corría de bruces, se arrastraba, como si tuviera muchos pies menudos. Es que no era hombre. Era una serpiente. Pero para los ojos de ella semejaba un mozo delgado y alto" (Lira, 1990: 40). La analogía de las características físicas entre la culebra y el "joven" son evidentes.

En los cuentos de Tayacaja, la muchacha pastora alimenta a la serpiente con leche de vaca; en el cuento del padre Lira, la muchacha alimenta a la culebra con harina. En el monte y durante el día la culebra vive debajo de una roca; análogamente en la casa de la muchacha vive debajo del batán. Las relaciones metonímicas entre pastora y leche y entre batán y harina son obvias. 
Murciélago seductor ${ }^{11}$. El R15 fue el único relato de este género registrado.

R15: Relato de Almendra Meza Torneros, natural de Rayán, Colcabamba, Tayacaja, registrado en 1971.

Una muchacha recibía en su estancia la visita nocturna de un joven. Éste siempre traía chicharrones que comían con papas o maíz sancochado. Pero él abandonaba la estancia antes de que amaneciera.

Cierta vez la muchacha no comió todo el chicharrón, hizo sobrar un poco con la finalidad de comerlo al día siguiente. Cuando amaneció al preparar el desayuno vio que el chicharrón que el muchacho traía era en realidad trozos de carne extraída de las heridas de los burros, mulas o caballos.

Entonces le entró la sospecha de que el "muchacho" que la visitaba no era un hombre sino era el masu (el murciélago). Por tanto, alisto un gran palo y esperó esa noche al visitante y cuando este llegó, la chica le dio muchos golpes y cuando cayó muerto al suelo, en efecto, vio la imagen de un murciélago. Así dicen que antes algunos animales andaban "engañando" a las muchachas que vivían solas en sus estancias cuidado a sus animales.

El murciélago se presenta ante la muchacha como un joven que la visita a su estancia por las noches. En un relato huanuqueño, el murciélago viste con prendas que lo identifican con un "misti", "mestizo" o "citadino" y es capturado con unos espinos y muere cantando a su amada. Hay metonimia entre el hábito nocturno del quiróptero y la visita nocturna del joven seductor. En un relato huanuqueño (Nieves, 1991), el visitante tiene un poncho negro que es la analogía de la piel del quiróptero

En el relato del Tayacaja, el quiróptero llegaba siempre trayendo "chicharrones" (trozos de carne del lomo de las bestias) mientras que la muchacha prepara papas sancochadas y hacía mote (maíz cocido).

Perdiz seductora ${ }^{12}$. El R16 fue el único relato de este género registrado.

R16: Relato de Maximiliano Campos, Natural de Palca, Salcabamba, Tayacaja, registrado en 1987.

La madre de un joven había sembrado papas. En su campo de cultivo la madre siempre encontraba huellas escarbadas por la perdiz. Entonces dijo al joven:

-Ve al campo de papas. Míralo, porque la perdiz está terminando con nuestras papas.

Cuando fue, en la cabecera del cultivo de papas, debajo de un andén estaba sentada una muchacha. Él empezó a conversar y ella le dijo:

-Vine por tus papas. Estuve escarbando para sacar algunas papas.

-Escarba nomas -dijo el joven.

Después de enamorarse el joven le dijo:

-Te llevaré a mi casa.

La muchacha aceptó. Se hizo llevar a su casa.

-Cuando te ausentes de tu casa me cubrirás con la olla-dijo.

Entonces el joven para ir a trabajar temprano cubrió a la perdiz con una olla y se fue. Cuando regresó por la tarde su madre le dijo:

- Hijo, habías capturado a esa perdiz. La encontré debajo de la olla. La maté - diciendo le sirvió la carne de la perdiz guisada. ¡La sirvió a su compañera!

Por la sorpresa, el cuerpo del joven hasta dijo ;Zas, Zas, Zas! Tuvo que comer a la perdiz, a su mujer. Después sacó el fémur del ave, con el que hizo una

11 Murciélago andino (Sturniro erythromos). En quechua le dicen masu.

12 Perdiz (Nothoprocta pentlandii'). En quechua le dicen yutu. 
flauta. Con la flauta el muchacho se fue hacia el cerro, iba tocando una música muy dulce [...].

La perdiz aparece ante el muchacho como una hermosa muchacha campesina durante el día y en el campo de cultivos de papas. La analogía del ave y la mujer se explican porque entre ambas hay un elemento común. En la cosecha la mujer participa recolectando los tubérculos. La perdiz todo el tiempo "recolecta" papas para alimentarse. También hay metonimia entre el fémur del ave, la flauta y la música.

El ratón seductor ${ }^{13}$. El R17 fue el único relato de este género registrado.

R17: Relato de María Ramos Huamán, Natural de la comunidad de Cedropampa, Salcabamba, Tayacaja, registrado en 1999.

Una chica vivía en su hatus (estancia), entonces, sólo por las noches, un joven iba a visitarla, hasta que adquirieron un compromiso. Tiempo después la muchacha apareció gestando. Entonces, el Ukush (el pericote) le llevaba todas las cosas necesarias para esa casa, nada le hacía faltar. Hasta que un día, la muchacha dio luz.

Pero el muchacho le visitaba sólo por las noches. Como de una semana después, la madre de la muchacha fue a visitarla a ésta. La muchacha había salido a cuidar sus vacas, mientras tanto su madre empezó arreglar la cama y encontró muchos ratoncitos recién nacidos; entonces dio muerte a todos los roedores. Cuando la muchacha llegó, viendo que su madre había dado muerte a sus hijos, lloró desconsoladamente. Entonces su madre preguntó: "¿Es que no vives aquí? En tu cama había parido un pericote". La muchacha no dijo nada, sólo estaba llorando. De pronto su madre le pregunta: "¿Tal vez tú pariste a los hijos del ratón?". "Sî́" respondió la muchacha. "Ahora se llevará todas sus cosas". Por la noche, el pericote hizo mucho ruido en la choza, y al día siguiente no amaneció nada, todas las cosas que trajo para la muchacha desaparecieron.

El ratón se presenta ante la muchacha pastora de vacuno como un joven que la visita a su estancia por las noches. Un relato acopiado por Lucila Quispe en el distrito de Mariscal Cáceres (Huancavelica) describe que el visitante es una rata que viste terno plomo y corbata blanca y enamora a una joven (BDA, 2002). El color del pelaje del roedor es análogo a la vestimenta del "misti", "mestizo" o "citadino" que son los que generalmente andan trajeados y que son diferentes de las usanzas de los campesinos.

El gorrión seductor ${ }^{14}$. El R18 fue el único relato de este género registrado.

R18: Relato de Cristina Enciso Reginaldo, natural de la comunidad La Loma, Salcahuasi, Tayacaja, registrado en 1998.

El Pichinkucha [gorrión] andaba sólo por las noches. El Pichinkucha iba a buscar muchachas. Durante alguna de esas andanzas, una de las muchachas lo había amarrado con su faja y luego fue a avisar a su hermana. Cuando volvieron, vieron que el Pichinkucha estaba amarrado en la cama con la faja de la muchacha, pero ya estaba muerto.

El gorrión está por el varón enamorador. Pero aquí se nota cierta pobreza analógica. Hay que buscar relatos de otros lugares para entenderlo en su plenitud. Sin embargo, el motivo de los pájaros seductores es amplio en la literatura oral. 
El “gentil" seductor. A este grupo pertenecen los relatos 19 y 20. El R19 será el referente de análisis y el R20 es presentado en el anexo.

R19: Relato de Juanito Medina, 28 años de edad, natural de San Antonio, Salcahuasi, Tayacaja, registrado en 1987.

Dos chicas estaban en su estancia y, cada noche, dos muchachos los visitaban. Nunca venían en el día. Llegaban sólo por las noches. Cuando escuchaban el canto del gallo, ellos se iban de inmediato.

Por eso las muchachas habían planeado invitarlos a una fiesta.

-Cuando vengan esta noche, como quien hace fiesta, los haremos amanecer en nuestra estancia -habían dicho.

Esa noche llegaron los muchachos. Cuando las muchachas invitaron, ellos tomaron asiento.

Cuentan que los muchachos vestían trajes elegantes. Vestía como los blancos. Esa noche empezaron a bailar. Los muchachos bailaban haciendo una rueda y "wapeando". Las muchachas también bailaban sin soltar a los jóvenes ni por un momento. Cuando estuvieron bailando así se oyeron el primer canto del gallo. En ese instante los muchachos dijeron:

- Ya regresaremos a nuestras casas.

Pero las muchachas, como habían planeado, no las soltaban.

-Esta vez amaneceremos -dijeron.

Entonces los "mistis" dijeron:

-¡Déjennos ir! ¡Déjennos ir!

Cuando así estuvieron rogando amaneció, entonces esos "mistis" se convirtieron en huesos y se derramaron por el suelo.

Entonces las muchachas dijeron:

-Estos muchachos habían sido "gentiles".

-Por eso vendrían por nosotras sólo por las noches.

El "gentil" se presenta ante la muchacha como un joven con traje elegante como el "misti", "mestizo" o "citadino". La contextura del esqueleto se dibuja presentando al "gentil" como joven delgado y elegante.

En otro relato registrado por Oswaldo Pari en Nuevo Occoro en Huancavelica (BDV, 2002), el "gentil" aparece como un joven indígena, con chalina blanca, poncho negro, pantalón de bayeta y ojotas. En Huarisca (Chupaca) el "Gentil" aparece como anciano. Las analogías de la vestimenta campesina y la apariencia de anciano son obvios.

\subsection{La simbología}

El perro en los cuentos de los seductores representa al "misti" (al blanco), al "mestizo", al "citadino" y al agricultor campesino. En otros contextos andinos el perro "parece que poseyera el estatus de no-animal y es considerado como ayudante y colaborador en el cuidado de los rebaños" (Flores, 1974: 257). Además, en la simbología andina el perro ocupa un espacio liminar entre la vida y la muerte, puede ver a las almas, cumple una función psicopompa, anuncia la muerte, protege de los condenados, cuando el dueño arde en el purgatorio le lleva agua en sus orejas, es oponente del diablo, los cachorros son utilizados para hacer jubeos, sus lagañas le permite ver a los espíritus, si una persona se unta los ojos con lagaña del perro podría ver a las almas, condenados y demás espíritus y podría enloquecer, el caldo de cabeza de perro cura a los enfermos mentales, entre los wanka el perro aun es sacrificado en honor de Wallallo.

Hay escasas referencias que aluden al perro como deidad. El Inca Garcilaso de la Vega describe que "antes de los Incas adoraron diversos animales, a unos por su fiereza, como 
al tigre, león y oso [...]. También adoraban a otros animales [...]. Adoraban al perro por su lealtad y nobleza" (1973a: 36).

Víctor Navarro del Águila registró un mito sobre tres héroes culturales surgidos de la laguna de Choclococha (Castrovirreyna, Huancavelica), uno se estableció entre los Chanka; otro entre los Pokcra; el último entre los Wanka. "Reinaron muchos años enseñando a los hombres las ciencias i las artes i lograron ordenar el mundo, i una vez terminada su misión, el que fuera padre de los Wanka se convirtió en un perro; el de los Pokcra en halcón; i el de los Chanka en león. [...] Desde entonces, los Pokcra divinizaron el águila indiana (el waman), los Wanka el perro peruano (el atokc: zorro) i los Chanka el león andino (el puma). De hecho se convirtieron en apukuna (dioses míticos) i se apellidaban: Apu Waman (Dios halcón), Apu Oskco (Dios León), i Apu Atock (Dios Zorro)".

Como afirman los arqueólogos no existe una etnia Pokcra; por tanto, debe tratarse de un mito modificado no hace mucho e hizo suyo el discurso de los intelectuales ayacuchanos que lo inventaron para proyectar un elemento identitario regional. Con relación al héroe que se convirtió en perro, surge una confusión porque en un momento se habla del perro y en otro del zorro. Pues, aun cuando ambos sean cánidos, perro y zorro son diferentes.

En cambio son más ricos los datos del perro como víctimas de sacrificio en honor de las deidades. En Dioses y hombres de Huarochirí el perro se torna en sustituto de los sacrificios humanos. "Cuando Huallallo, de vencedor, cayó vencido y huyó, fue sentenciado por [Pariacaca] a comer perros, por haber sido antes devorador de hombres. También ordenó que los huancas le adoraran; y, como su dios comía perros, también los huancas le ofrendaban estos animales y ellos mismos se alimentaban de perros. Y es esa la razón de por qué hasta ahora a los huancas los llamamos comeperros" (de Ávila, 1966: 73). Tanto Garcilaso de la Vega (1973a) como Guamán Poma (1988) hacen anotaciones semejantes. El último especifica que los indios del Hanan Wanka, Jauja (Hatun Xauxa) y Urin Wanka sacrificaban y comían perros.

Del mismo modo, el perro ha sido soporte de varios mito-creencias. Así, durante el incanato pensaban que el eclipse de Luna era porque ésta se enfermaba y que podía caer y matar a todos. Por eso al empezar el eclipse tocaban cuanto instrumento hiciese ruido y “[...] ataban los perros grandes y chicos, dábanles muchos palos para que aullasen y llamasen la Luna, que, por cierta fábula que ellos contaban, decían que la Luna era aficionada a los perros, por cierto servicio que le habían hecho, y que, oyéndolos llorar, habría lástima de ellos y recordaría del sueño que la enfermedad le causaba" (Garcilaso de la Vega, 1973a: 120). Los gritos buscaban que "la Luna resucite" (Arriaga, 1961).

Por el incanato se creía que el aullido de los perros ahuyentaba a las heladas. Este mitocreencia todavía está presente en la memoria de los agricultores en el valle del Mantaro y las partes altas de las cordilleras.

Guamán Poma narra que los indios yungas de los llanos hasta Quito y Nuevo Reino "enterraban a sus difuntos con perros" (1998: 211). En efecto, las investigaciones arqueológicas corroboran la presencia de restos de perros en las tumbas y que tendrían una clara función de guía de las almas al más allá (Goepfert, 2008).

Cieza de León habla de ciertas "malas costumbres de los indios" que viven en el interior de los Andes, que fue informado por un español vecino de villa de Plata que "tomó a una india y a un perro cometiendo este pecado, y que mandó quemar la india" (1973: 220). Otros españoles le informaron "que oyeron que indios suyos cómo en la provincia de Aulaga parió una india, de un perro, tres o cuatro monstruos, los cuales vivieron pocos días" (1973: 220).

Hasta ahora gran parte del mito-creencia que tiene su soporte en el perro está vigente en algunos ritos, en las prácticas de la medicina tradicional, en los diversos relatos como en los cuentos sobre los seductores, los condenados, las almas y los diablos; en ciertos mitos de origen y en los sueños y su simbolismo correspondiente. La crónica de Cieza de León, más allá de su mirador etnocéntrico occidental y aun cuando refiera a otras áreas y otros tiempos, 
tiene cierta afinidad con los cuentos del perro seductor.

$$
* * *
$$

El aqchi en los cuentos de los seductores aparece representando al "misti" (al blanco), al "mestizo", al "citadino" y al campesino agricultor. Hay personas que le dicen "El caballero" por su connotación masculina, ave apuesta y elegante, pero que sutilmente subraya al otro radical y dominante.

Otrora esta ave fue sagrada y estuvo relacionada con los símbolos de poder entre los Incas. Garcilaso de la Vega lo identifica como corequenque, escribe que el Inca "traía [...] en la cabeza [cuando estaba sin la borla] otra divisa más particular suya, y eran dos plumas de los cuchillos de las alas de una ave que llaman corequenque" (1973b: 174). Las plumas eran sagradas por estar asociadas a los primeros incas. Para obtener las plumas "cazaban las aves con la mayor suavidad [...] y quitaban las dos plumas, las volvían a soltar, y para cada nuevo Inca que heredaba el reino las volvías a prender y quitar las plumas, porque nunca el heredero tomaba las mismas insignias reales del padre, sino otras semejantes" (1973b: 175).

El carácter sagrado del ave es descrito también por Pedro Sarmiento de Gamboa, cuyo nombre habría sido "indi", era aquel que "Mango Capac" traía consigo desde "TampuTocco", “... al cual veneraban todos y le temían como a cosa sagrada..." (1988: 54). Los sucesores "Mango Capac" lo habían tenido cerrado en "... una petaca o cajón de paja, que no la osaban abrir, tanto era el miedo que le tenían, mas Mayta Cápac, como más atrevido que todos, deseoso de ver qué era aquello que tanto guardaron sus pasados, abrió la petaca y vido el pájaro indi y habló con él; ca dicen que daba oráculos. Y de aquella confabulación quedó Mayta Cápac muy sabio y avisado en lo que había de hacer y de lo que le debía de suceder" (1988: 69).

Antonio de Alcedo anota que el "Curiquingui, O Beteado de oro, llamada también Ave del Inca: en Perú es mayor que una Gallina, con las alas, y la cola mas largas: es de color pardo claro, manchado de ondas de amarillo muy subido, ó color de oro, por lo que le dan el nombre: es ave casi tan doméstica como las Gallinas, rara vez se ve sola, y vuela poquísimo al salir de sus dormidas hasta unirse muchas en los campos y prados donde están dando carreras todo el día, limpiando y purgando la tierra de insectos hasta retirarse a dormir por las noche: es enemiga de las culebras que embiste poniendo por escudo el ala para defenderse de sus picadas hasta que la mata, y separa la cabeza para comer el resto. Dicen los naturales del Reyno de Quito que si alguna vez la muerde la culebra corre apresurada á buscar una yerba con la que se libra del veneno" (1789: 74).

Actualmente en la tradición oral y folklore ecuatoriano, el Corequenque es identificado con el mismo aqchi. Algunos estudiosos dicen se trataría de un colibrí dorado y no del matamico. Inclusive se dice que sería una especie extinguida, mientras que otros aseguran haberlo encontrado en algún territorio de los Andes Centrales de Perú.

En los cuentos estudiados ya no quedan vestigios del carácter sagrado del aqchi. Más bien se trata de relatos que han metaforizado la construcción de las otredades de quienes se debe temer y desconfiar.

$* * *$

La culebra en los cuentos de los seductores aparece representando al "misti" (al blanco), al "mestizo" y al "citadino". Es un símbolo fálico por excelencia. Representa a las fuerzas ctónicas pero también aparece como los rayos del dios sol (con carácter uránico). Representa al agua, al aluvión, a la granizada, a la cordillera. En quechua se denomina Amaru y tiene carácter sagrado. Lorenzo Tacca (2010) ha registrado que la sachamama es una serpiente de dos cabezas que se convierte en arco iris y que yacumama (nombre de la serpiente en otros contextos) se convierte en un rio o en rayo.

Los cronistas tienen diversos registros del carácter sacro del amaru. Guaman Poma atri- 
buye a Manco Cápac pertenecer a la casta de "los amaros y serpientes", que por no haber tenido padre conocido le dijeron "hijo del sol" cuya madre fue Mama Uaco y que sería hijo del Amaro (1980: 58-60). Este mito dice que la serpiente se reprodujo en una mujer. Los cuentos contemporáneos sobre la serpiente seductora podrían ser producto de la devaluación de este y otros mitos antiguos.

Francisco de Ávila registra la afinidad de la serpiente con el agua, la agricultura y la fertilidad. Pariacaca para ganarse el amor de Chocasuso, mujer hermosa del ayllu Copara en Huarochirí, cuyas chacras estaban "muy necesitadas y faltas de agua con que regarse", promete hacer un canal y mandó que se juntasen todas las aves, las culebras y lagartijas, osos, tigres, leones y demás animales y ordenó: “... que con mucha brevedad desmontasen todo aquello por donde parecía haber de proseguir la dicha acequia; lo cual hicieron. Y hecho, les volvió a mandar que echasen cordel y ensanchasen la zanja que había y prosiguiesen con otra nueva hasta las chacras [...], el raposo ${ }^{15}$, con sus mañas y razones, salió con que habla de ser el acordelador y así, estando haciendo su oficio y llegando a aquel lugar que ahora está por encima de la iglesia de San Lorenzo, con su cordel, vino de lo alto una perdiz volando y [...] venía haciendo [...]: Pich, pich, y el descuidado raposo diciendo: Huac, turbado, rodó por el cerro abajo y luego, todos los gastadores y peones que a la mira estaban, con grande enojo y enfado de lo sucedido, mandaron a la culebra que subiese y ella echase el cordel y prosiguiese lo comenzado. La cual lo hizo, pero no tan bien como de antes lo hacía el raposo [...] (Ávila, 1966: 215-217).

Como se ha visto, zorro y culebra están relacionados con el agua. No obstante en otros contextos la serpiente es solar y el zorro es lunar. Hasta ahora los campesinos se guían por los aullidos del zorro para prever temporadas de abundantes o escasas aguas. Si bien es cierto que la serpiente es identificada directamente con el agua y es semen germinal (Cáceres, 2002).

La serpiente es también el origen de las enfermedades de los humanos. En la mitología de Huarochirí (ver Ávila, 1966 y Taylor, 2008), Huatiacuri (hijo de Pariacaca) obteniendo el saber por la plática de dos zorros, cura la salud de Tamtañamca, quien estaba enfermo a raíz de la "relación culpable" de su mujer con otro hombre y que por dicha culpa vivía encima de su bella casa una serpiente y un sapo con dos cabezas debajo del batán a las que debían dar muerte.

En los cuentos materia de este estudio y en "La amante de la culebra", registrada en Cusco por el padre Lira (1990), la serpiente vive debajo del batán, la muchacha duerme en una habitación o en una cama contigua al batán del cual sale por las noches para dormir con ella. En los cuentos de Tayacaja la mujer alimenta a la serpiente con leche de vaca, en el cuento cusqueño se alimenta con harina. En ambos casos, la comunidad da muerte a la serpiente y a las crías.

Los relatos sobre la reproducción de las culebras cambian también de formas. Así hay mito-creencias huancavelicanas que consideran que la mujer que recoge agua del manantial en plena llovizna o cuando hay arco iris, puede alumbrar sapos y culebras. En el sur peruano, la atracción de las mujeres o varones por el arco iris es por el color de las ropas que visten (Valderrama y Escalante, 2000). En las tradiciones de Huarochirí, Huancavelica y el sur andino, la serpiente y el batracio están relacionados con el agua.

Arguedas e Izquierdo dan cuenta de un relato registrado en Pillao, Pasco, en la que un sueño revela a una mujer que daría luz dos huevos que los colocaría en un mate y que depositara leche todos los días. El sueño le dice que las serpientes serían sus hijos y que las amamantara. Otro sueño le advierte que huya sin voltear, porque las serpientes exterminarán a toda la gente del lugar. Dos indios que salían de las montañas, que sabían "que las serpientes no ven a la salida del sol, las esperaron a esa hora, en las alturas de un cerro; y así fue como

15 En la traducción de Gerald Taylor (2008) es nominado específicamente como el zorro. 
cortaron las cabezas de las serpientes" (2012: 46).

En otro cuento registrado por Arguedas en Lucanamarca, la gente del pueblo sentencia a la madre de un lagarto devorador de mujeres: "Después de que mueras, una serpiente mamará de uno de tus pechos y del otro un sapo. Ese será tu castigo" (1986: 109).

En otros contextos culturales (como en la comunidad de Huanusco en Parihuanca), la papa shukre se convierte en culebra por las noches. El shukre blanco es culebra blanca y el shukre negro es culebra negra, dicen que pelean entre ellas, por eso las pirwas (depósitos de paja) se desgastan rápido.

Finalmente, el discurso cristiano fue re-interpretado por los pobladores de la zona estudiada. Así un anciano en la comunidad campesina La Loma, me narró que en tiempos muy antiguos la culebra caminaba erguida como las personas. Pero cuando la Virgen venía montada en un burro, la culebra la hizo asustar. Luego le conversó a la Virgen pero ésta no contestó. Cuando irguiéndose más la culebra le volvió a hablar a la Virgen, ésta dijo: "Cuando yo haga la señal de la Cruz con la mano izquierda, tú dejarás de andar erguida y andarás como cualquier sabandija arrastrándote. No debiste asustarme". Desde ese día, la culebra camina con los brazos y píes dentro de su propio cuerpo.

***

El murciélago en los cuentos de los seductores aparece representando al "misti" (al blanco), al "mestizo" o al "citadino". Manuel Nieves (1991) ha registrado un relato en Huánuco en la que el murciélago visita a una joven soltera como un galán apuesto, con una guitarra y con poncho negro. Después de las sospechas de la joven, el murciélago es atrapado en espinas y muere cantando a su amada: "Déjame mamita, déjame paloma, no partas mi corazón, que me muero por tu amor".

Más arriba vimos que Lévi-Strauss relaciona al murciélago con el origen de ciertos bienes culturales e instrumentos musicales. El relato huanuqueño se convierte en una evidencia más contemporánea de los registros de nuestro antropólogo. La consideración mitológica de las cuevas como las paqarinas de los hombres no está lejos de una analogía con los quirópteros que suelen residir en las cavernas.

Por el área estudiada hay murciélagos. Por las noches ingresan en las viviendas de los campesinos o chozas de los pastores, hacen sentir su presencia con sus aleteos, dan unas vueltas y se van. En el cuento comentado el murciélago visita a las muchachas sólo por las noches y antes del amanecer se va. Cuando los caballos o mulas aparecen con heridas en el lomo, los campesinos afirman que fueron mordidos por el murciélago. En el cuento el joven-murciélago trae cada noche "chicharrones" que más adelante descubre la muchacha que eran los trozos de carne arrancada a los équidos.

Guaman Poma de Ayala describe al murciélago como un animal de mal agüero, que si ingresa a una vivienda, los habitantes de la misma pueden morir. De otra parte, presenta un dibujo titulado "OTABO CALLE PUCLLACOC" que tiene las inscripciones "de edad de cinco años" y "niño de la doctrina" (1988: 145). Describe que son los niños que servían a sus padres haciendo jugar a los menores o ayudan a criar a los huérfanos y que éstos estaban en edad apropiada para recibir doctrina y escuela y que sean castigados y adoctrinados por todo el reino "por la orden del Reyno y la buena ley" " (1988: 149).

El niño del dibujo está en un campo abierto. Está descalzo. Juega con su mano derecha con una honda del cual sale disparada una piedra. Viste una especie de camisa sin magas. En la cabeza trae un tocado con un murciélago. Sobre este tocado no dice nada Guaman Poma.

González, Rosati y Sánchez (20o2) afirman que el tocado recuerda al uso de indígenas en otros lugares del área andina y que son confeccionados con la piel completa un murciélago. Los autores afirman: "El tocado que lleva el niño significaría que desde esta edad está en condiciones de ser elegido para ser sacrificado" (2002: 152). En efecto, las culturas prehispánicas no han estado exentas de los sacrificios humanos. Pero hay que considerar que si el 
sacrificio lleva a la muerte, también "garantiza" la vida de los sacrificantes.

¿Y qué hay del murciélago en los registros arqueológicos? En el lanzón de Chavín (900 a.C. - 200 a.C.), algunos estudiosos encuentran que la figura principal es una divinidad antropomorfa felinizada. Otros, como Burger (citado por Juanita, 2005), sostienen que parece haber un murciélago arriba de la nariz. Del mismo modo se argumenta que la figura central de la Estela de Raimondi es un murciélago. En esta última tendencia se ubican los estudios de Wong (2009) y Wong y Arbaiza (2010).

Antonio Wong muestra la relación entre las representaciones más importantes de estilo de la cultura Chavín y la representación gráfica del murciélago como expresión simbólica de un grupo social de origen eminentemente selvático, cuya influencia habría sido por las oleadas migratorias y la cercanía de Chavín con la selva.

En otro trabajo, Wong y Arbaiza apoyándose en la tradición oral de diversos pueblos amazónicos postulan que este culto se habría expandido "por la presencia de grupos pertenecientes al tronco lingüístico jibaro, en el cual están comprendidas las lenguas aguaruna, achuar, awajun, wampis, huambisa, jibaros" (2010: 344). También hablan de un mito awajun referido al murciélago (Aetsetseu - El cortador), en la que el quiróptero canta “Aetsetseu, aetsetseu, como si fuera pajarito dashipkit voy a saltar. Aetsetseu, aetsetseu como pajarito dashipkit voy a saltar. Aetsetseu, aetsetseu, aetsetseu, aetsetseu voy a saltar como pajarito dashipkit. Aetsetseu, aetsetseu, aetsetseu, aetsetseu” (2010: 345). Lo anterior coincide con los estudios de Lévi-Strauss que relaciona al murciélago con el origen de ciertos bienes culturales entre ellos los instrumentos musicales. Del mismo modo, uno de los relatos contemporáneos presenta al quiróptero como un joven galán que toca la guitarra y que muere cantando.

Entre los estudios de la cultura Mochica (200 - 700 d. C.), el arqueólogo Nicolás Goepfert da cuenta del hallazgo, en la Huaca de la Luna, de un conjunto de sepulturas con nuevas evidencias de ofrendas de camélidos, cánidos, cuyes, aves y murciélagos. Se interpreta este simbolismo como una función psicopompa y alimentario. En la iconografía mochica, el murciélago estuvo asociado "al sacrifico humano por desangramiento" (Goepfert, 2008: 242).

Todo lo anterior permite afirmar que el relato del murciélago seductor son textos devaluados de mitos que, aunque presenten reminiscencias de su origen, se han convertido en cuentos para metaforizar a las otredades étnicas.

$$
* * *
$$

La perdiz aparece en el cuento comentado representando a la mujer del campo, contraria al agua, con características anti-agricultura, es parte del alimento humano y da origen a la flauta.

Cuando el muchacho, enviado por su madre, va a revisar el cultivo de papas, encuentra a una bella muchacha campesina, que le dice que está recolectando algunos tubérculos de su chacra. El muchacho se enamora y le pide que vaya con él a vivir a su casa. En otro cuento, registrado por Jeison Huarca (s/f), la perdiz se enamora de un pastor, al mojar sus alas se convierte en una mujer encantadora y pide posada al pastor hasta que pasen las lluvias.

Rodolfo Sánchez resume los registros de Molina y Cobo y escribe: "Las estrellas se conciben frecuentemente como aves magníficas, tales como unas guacamayas hermanas que bajan del cielo para robar papas, una de las cuales es obligada a casarse con el campesino que la captura" (2011: 22). Este mitema es igual al encuentro del joven y la muchachaperdiz del cuento estudiado, ambas son aves, ambas extraen papas, ambas se quedan con el varón.

Existe una canción quechua que dice “Ay yutuchallay, purumpi yutuchallay. Paralla chayamuptin, waqakullachkanki. Paralla chamuptin, llakikullachkanki” (Ay perdiz, perdiz en el monte, cuando llega la lluvia, estás llorando, cuando llega la lluvia estás triste). De esta 
canción se puede deducir que la perdiz está asociada con lo seco, lo soleado, lo caliente que lo hace ave solar.

Lo anterior sirve para plantear que la perdiz es un ser anti agricultura. Recordemos que en Dioses y hombres de Huarochirí, cuando Viracocha mandaba construir una acequia para los campos de cultivo de Cavillaca y su ayllu, el vuelo y graznido de la perdiz hizo rodar al zorro que era el acordelador para el ensanchamiento de la acequia y que por esta razón el agua no llegó hasta el espacio adecuado ni tuvo la cantidad suficiente (Ávila, 1966; Taylor, 2008; Millones, 2010). Aquí se nota con mayor precisión la oposición de los seres lunares y solares. El zorro está relacionado a lo húmero, lo lluvioso, lo frío, que lo hace un animal lunar en oposición a la perdiz que es ave solar.

Pero la cualidad anti agricultura de la perdiz también aparece de modo directo cuando el ave, para sobrevivir, tiene que escarbar la tierra y obtener los tubérculos. Esto sucede desde el momento de la siembra hasta la cosecha. Puede sacar las semillas depositadas en la tierra o sacar los nuevos tubérculos para alimentarse. De ahí que los campesinos tengan que cuidar sus parcelas intentando cazar a las perdices.

La carne y los huevos de la perdiz son muy apreciadas. Generalmente en el campo todo varón desde niño lleva consigo un tirapiedras que sería la versión moderna de la waraka, que da mejor precisión para cazar aves. Las perdices son cazadas de vez en cuando por los varones. En cambio, la recolección de huevos es realizada más frecuentemente por las mujeres que al estar apacentando sus animales las pueden encontrar.

En el cuento comentado, la "muchacha" vive cubierta por una olla y es descubierta por la madre del muchacho que la cocina y la hace comer a su amada. Entonces el joven, fabrica una quena del fémur de la perdiz cuya melodía es siempre melancólica. Jeison Huarca (s/f) describe que el joven repite un canto muy triste: "Pirr, pirr, pirr Tu madre me capturó... Tu madre me mató... Tu madre me cocinó... Tu madre me saboreó y luego me comió". El relato metaforiza la preferencia de las uniones endogámicas, aunque puedan existir uniones de un miembro de una comunidad con el de otra, entonces, la muerte de la perdiz metaforiza la rivalidad de la nuera con la suegra en un contexto patrilocal.

En términos generales hay mitos andinos que explican el origen de la quena a raíz de la pérdida de una amada, cuyo amante saca un fémur del cadáver de ella y fabrica la quena. Da la impresión que estamos ante una mutación de forma, hay cambio de la muerte de la mujer por el de la perdiz. Igual que en el mito del murciélago estamos ante los orígenes de ciertos bienes culturales que se habrían devaluado transformándose en cuento.

$$
* * *
$$

El ratón aparece representando al varón no-campesino. El relato acopiado por Lucila Quispe (BDA, 2002) narra que una rata se enamora de una chica y que por la noche aparece con terno plomo y corbata blanca. Estamos ante una figura analógica de un varón que viste como citadino ("misti"). En el relato nuestro, la mujer es pastora; en cambio el roedor se relaciona negativamente con la agricultura, específicamente como consumidor de cereales tanto en el campo como al interior de las viviendas campesinas.

Sin embargo, en otros relatos el ratón simboliza la laboriosidad y la tendencia a acumular los frutos de la recolección. Este hecho lo opone al pájaro carpintero - Colaptes rupicola, que en vez de acopiar productos se las pasa cantando y cantando (Taipe y Orrego, 1997b).

En el cuento mentando, el ratón no le priva de nada a la muchacha, pero cuando fue descubierto y muerto sus críos, el ratón se irá llevando todas sus cosas. Entonces también estamos ante la figura en la que el roedor representa la abundancia.

El gorrión representa al varón enamorador ¿Local o extraño? Se puede presumir que es extraño, pero no en el sentido de la otredad étnica, sino que da la impresión que estaría metaforizando al varón de otras comunidades. Es decir, podríamos estar ante la metáfora de preferencia del matrimonio endogámico. 
La trama de este relato existe en otras culturas amazónicas. Así un mito "arahuaca ashéninca", habla de la muchacha y el pájaro satotore. En resumen, los padres salen a pescar. La muchacha queda sola en su cuarto. Vino el satotore como persona y la enamora. Vive en la casa cubierto con una olla de barro. Los padres descubren al pájaro. Agarró al satotore, lo amarró y lo mató (Ortiz, 2004).

En tiempos míticos Viracocha se enamora de la doncella Cavillaca con quien todas las huacas querían dormir sin conseguirlo. Cierto día ella se puso a tejer debajo de un árbol de lúcumo. En ese momento Viracocha se convirtió en pájaro y subió al árbol donde tomó el fruto y echó su germen masculino e hizo caer el fruto frente a la mujer. Ella tragó el germen y de ese modo quedó preñada, si haber tenido contacto con ningún hombre. Después de nueve meses parió a una doncella (Ávila, 1975; Taylor, 2008; Millones, 2010).

La referencia del satotore ilustra que los relatos de las aventuras de las aves no fueron aisladas, sino que según iban viajando en el tiempo y espacio se iban contextualizando a las realidades donde circulaban. Sin embargo, parece que sus antecedentes están en algunos mitos más antiguos. Así, Arguedas e Izquierdo (2012) tienen registros que dan cuenta de que el hijo de un curaca se transforma en pájaro para ingresar al palacio de la hija de otro curaca; embaraza a la joven; el padre descubre el ardid y manda que lo maten; madre e hijo se arrojan al mar y se convierten en las islas de Pachacamac. Del mismo modo, cuando Curinaya Viracocha perseguía a Cahuillaca, llegó hasta las orillas del mar hasta donde estaban dos hijas de Pachacamac, cuya madre (Urpay Huáchac) había entrado al mar para visitar a Cahuillaca; Curinaya Viracocha, aprovechando su ausencia, violó a la hija mayor; cuando quiso hacer lo mismo con la otra, ésta se transformó en paloma y alzó el vuelo (Âvila, 1975; Taylor, 2008).

$* * *$

El "gentil" representa al varón de procedencia étnica y generaciones diferentes. Se presentan ante las muchachas como "misti" que viste traje elegante. Por Nuevo Occoro (en Huancavelica), el "gentil" aparece como un joven indígena, con chalina blanca, poncho negro, pantalón de bayeta blanca y ojotas (Oswaldo Pari en BDV, 2002). Por Huarisca (Chupaca, Junín) el "gentil" es representado como anciano con poderes que pueden enfermar y provocar la muerte de las personas que profanan sus espacios (Taipe, 2005).

En todos los casos, el "gentil" es de la otra humanidad, es un ser del inframundo que, por haber quebrado las reglas básicas de la convivencia social, fue exterminado por lluvia de fuego y la emergencia de dos astros solares, pero que no está muerto "totalmente", porque su existencia afecta aún a los humanos de las generaciones actuales.

En nuestros relatos el "gentil" llega sólo por las noches a seducir a las pastoras, pero antes del tercer canto del gallo tiene que irse. Cuando la muchacha o las muchachas las retienen bailando Santiago hasta el amanecer, éste recobra su forma de esqueleto y sus "huesos se desparraman".

Semejante al baile de Santiago, en el cuento la "Danza de la luna llena" de Juan Ayuque, comentado por Rommel Plasencia, “[...] el gentil participa como bailarín en la fiesta de la trilla del plenilunio y luego, al amanecer, solo quedan sus huesos" (Plasencia, 2012: 71).

El gallo es un símbolo solar. Su canto anuncia el advenimiento del astro (Chevalier y Gheerbrant, 1986). Valderrama y Escalante (2000) afirman que el canto del gallo "simboliza el inicio de otro tiempo" porque "separa la noche del día, así como de un tiempo de otro". La aparición solar se impone sobre la noche derrotando o anulando a los poderes asociados al inframundo y la obscuridad como el de los "gentiles".

Con el "gentil-misti" estamos ante una construcción de la alteridad étnica radical (indio/ misti). Con el "gentil-indígena" estamos ante la metáfora de diferencia intergeneracional moderada. En el caso del "gentil-anciano" estamos de cara a una diferencia intergeneracional radical. 


\section{La seducción: Tiempo, espacio y reproducción}

Los encuentros entre los seductores y los jóvenes (mujeres y varones) suceden generalmente por las noches y excepcionalmente durante el día. La noche parece ser el aspecto temporal preferido para que se operen transformaciones de animales y esqueletos en humanos y se consuma la seducción.

La mayoría de los encuentros sexuales ocurre en espacios no culturizados o semi culturizados como el cerro, la estancia y la chacra. Los encuentros de la perdiz, el gorrión, un relato del perro y otro de la culebra acontecen en espacios plenamente culturizados como la casa de la mujer o del varón.

Cuando el encuentro de la culebra se da en el monte o la estancia, por el día vive debajo de una roca y de noche ingresa a la choza como hombre. Cuando se trasladan a la casa de la mujer, la culebra vive debajo del batán. Cuando la mujer hace uso del batán, lo hace con las piernas abiertas, por tanto, permite que la culebra la penetre. Por las noches puede salir $\mathrm{y}$ transformarse en humano e ingresa al lugar donde duerme la mujer. En algunos casos la mujer la alimenta poniendo un recipiente con leche junto al batán. En el relato registrado por el padre Lira, la serpiente es alimentada con harina.

La culebra de nuestros relatos habita en climas de templado a frío. Y en este contexto el reptil es masculino. En contraste, en estas mismas sociedades, en climas de templado a cálido habita una serpiente de colores denominada "sortijilla", que en oposición a la culebra=masculino la "sortijilla" es femenino. En los carnavales de esta zona las mujeres cantan: "Camino realpi sortijillaschay, anchuriy hinari, saruimaruykiman" ("Sortijilla en el camino real, hazte a un lado, retírate que te podría pisar"), estamos ante una metáfora que hace alusión sexual donde la "sortijilla" está por la mujer. Los hombres no cantan, sólo bailan. Entonces quienes "pisarían" a la serpiente son los varones.

El encuentro del joven con la perdiz ocurre en el día y en el campo de cultivo, la perdiz aparece para el muchacho como una chica guapa escarbando algunas papas. Pero la "convivencia" se realiza en la casa del varón, porque la perdiz va a vivir a la casa del joven y lo hace clandestinamente igual que la serpiente, cuando el varón sale a trabajar, la perdiz queda cubierta por una olla. En cambio por las noches llevan vida de pareja.

El encuentro del gorrión y su amante acontece en la casa de la muchacha, es capturado y muerto en la habitación de la mujer. Alejandro Ortiz (2004) describe un relato semejante entre los arahuaca ashéninca en el que el satotore (especie de pájaro rojo con ojos grandes) enamora a una muchacha y vive en la casa de ella cubierto con una olla. El padre de ésta la captura y da muerte al pájaro.

Uno de los encuentros sexuales del perro ocurre en la casa de la muchacha, pero en otros tres cuentos ocurren en las estancias. Este hecho podría ser reflejo que en la vida real los perros viven tanto en la casa como en las estancias. Entonces con facilidad aparece como seductor en ambos espacios. En contraste, el murciélago, el ratón y el gentil realizan las seducciones sólo en las estancias.

De dichas relaciones sexuales sólo en un caso la mujer llega a parir el hijo del perro y otras paren los hijos de la culebra y el del ratón. Vimos más arriba que está claro que la reproducción de animales machos en mujeres existe en varios mitos andinos. Nuestros cuentos podrían ser textos modificados y devaluados de dichos mitos.

Uno de los cuentos señala que "en tiempos antiguos dicen que no hubo jóvenes. Por tal razón los animales 'engañaban' a las chicas". El "había una vez" o el "cierta vez" que caracteriza a los cuentos diferencia a los mitos que temporalmente remiten a lo primigenio, a los "tiempos antiguos".

Otros dos relatos señalan explícitamente que se trata del origen de las serpientes. Dar cuenta del origen de las cosas en el mundo o sus modificaciones es una de las características del mito. En el relato de la perdiz parece que estamos de cara al origen de la flauta andina 
fabricada del fémur del ave. Es clara también la reminiscencia del origen de algunos elementos culturales en el relato del murciélago.

\section{Las alteridades en los relatos}

Para comprender las alteridades subyacentes en los relatos sobre los seductores hay que ubicarse en el contexto temporal, político, social, económico y ecológico en los cuales se produjeron, circularon y consumieron los mismos.

Queremos llamar la atención sobre tres aspectos. Primero, recurrentemente aparecen en todos los relatos los animales y "gentiles" representando a la otredad. Los actantes son descritos con signos de estar representando al "misti", al "mestizo", al "citadino" y al campesino (indígena).

"Misti" es la categoría que designaba al hacendado, por tanto, al blanco, al patrón. El contexto en el que surgieron estos relatos estaba definido por la coexistencia conflictiva entre haciendas y comunidades. El "misti" se oponía al campesino en su condición de comunero libre o siervo de hacienda.

En la categoría "mestizo" estaban el administrador, el capataz y demás empleados de la hacienda, en consecuencia también entre éstos y los campesinos de comunidad y hacienda había relaciones conflictivas.

Habría una tercera categoría, el "citadino", a quien los campesinos podría identificar unas veces como "misti" y otras como "mestizo", y designa a los docentes, empleados de salud, feriantes, comerciantes ambulantes de ganado, los transportistas, el cura y los músi$\cos$.

En la categoría campesino estaba aquel que pertenece a una comunidad libre o a la hacienda. Pero son muchas las comunidades y que entre ellas también tejieron y tejen sus propias solidaridades, tensiones y conflictos.

Las oposiciones expuestas también adoptan las formas de valle/puna, ciudad/campo, castellano/quechua y letrado/analfabeto. Los relatos provienen de sociedades asentadas en alturas, en el campo, de habla quechua y con cultura predominante oral. El "misti", mestizo y "citadinos" ocupan el valle, la ciudad, hablan el español y son letrados.

¿Cómo se relaciona lo anterior con los relatos sobre los seductores? Si bien los jóvenes (hombres y mujeres) se iniciaban entre miembros del mismo grupo o de otras comunidades, también podían hacerlo con hombres pertenecientes a sus otredades no-campesinos. Sin embargo, las mujeres fueron además víctimas de abusos sexuales por los hacendados y sus hijos, por sus empleados y por algunos hombres pertenecientes a la categoría del "citadino". En una situación como esta los relatos metaforizan a los "otros" de quienes se debe temer y desconfiar radicalmente, así resulta explicable porqué los animales y el "gentil" estén por el "misti", el "mestizo" y el "citadino".

Segundo, hay un grupo de relatos en el cual los animales y el "gentil" presentan signos campesinos (indígenas). Tanto los seductores que representan a las categorías no-indígenas como los que representan a los seductores con signos indígenas son muertos por un grupo de comuneros, por el padre, la madre, la hermana o por la misma joven seducida.

Si en el primer grupo de relatos comentados se construye el rechazo al "no-campesino", en el segundo grupo se construye el rechazo al campesino (varón o mujer) ajeno a la comunidad. Si el anterior grupo rechaza la exogamia étnica, el segundo grupo rechaza la exogamia que involucra a las comunidades campesinas circundantes. Sin embargo, el segundo no sería absoluto ya que entre algunas comunidades tejen alianzas e intercambian mujeres, pero con otras no los hacen.

Tercero, contemporáneamente los antiguos integrantes de la categoría "misti" fueron modificados. La reforma agraria y los movimientos y gestiones campesinas terminaron por desaparecer a los hacendados y sus colaboradores. Surgieron nuevos grupos locales de po- 
der que controlan los municipios, la gobernación y los juzgados de paz, que acceden a los empleos en el sector público con presencia en el área rural, otros consolidan su dominio económico como comerciantes que venden y acaparan productos y los últimos son transportistas que son las bisagras directas entre el campo y la ciudad.

Lo "misti" se ha redefinido para referir a los integrantes del nuevo grupo de poder local, pero también para referir a los habitantes de la ciudad especialmente de aquellas capitales distritales y provinciales con avances de modernización urbana.

De otra parte, ya no prima la endogamia comunal, ahora los jóvenes tienen libertad para elegir sus parejas con sus pares de otras comunidades o poblados. En las ciudades a donde han migrado los jóvenes tienen la misma libertad para hacer pareja con mujeres procedentes de la misma o de otras comunidades, de otras provincias y otras regiones.

Por último, quienes son aun parte de la producción, circulación y consumo de los relatos sobre los seductores, metaforizan a las otredades antiguas, y ahora son vehículos para metaforizar a quienes integran la categoría del "misti" redefinido, aunque esta construcción ya no es tan radical como antaño.

\section{Conclusiones}

Los relatos sobre los seductores reflejan los contextos sociales, económicos, culturales, temporales, espaciales y físicos en los cuales fueron producidos, circulan y son consumidos.

Los seductores son el perro, el aqchi, la culebra, el murciélago, la perdiz, el ratón, el gorrión y el "gentil". Siete de ellos tiene connotación masculina y uno es de connotación femenina. Los actores humanos son campesinos jóvenes de ambos sexos, con la intervención de los familiares y otras personas de la comunidad.

Los relatos presentan asociaciones diversas entre los seductores y los jóvenes determinados por la actividad económica, la ecología y los hábitos de los animales.

Las analogías están construidas en base a las características físicas, los hábitos de los animales y los signos manifestados en la "vestimenta" de los seductores.

Los actantes animales, en cuanto símbolos, presentan una polisemia impresionante que vienen de otros contextos temporales, se hacen presentes y se proyectan al futuro.

Casi todos los cuentos presentan signos de su origen mítico que en el viaje temporal y espacial habrían ido perdiendo su carácter sacro y hoy apenas quedan huellas borrosas de su función de dar cuenta del origen o la modificación de las cosas en el mundo.

El sentido subyacente de estos relatos es la construcción de las otredades radicales y menos radicales con el no-campesinos y con el campesino externo a la comunidad. En consecuencia, se puede inferir la preferencia de antaño de estas sociedades por el matrimonio endogámico.

La categoría "misti" ha sido resemantizada, ahora se reconoce como "misti" al nuevo integrante del poder local (entre los que pueden estar los mestizos y los citadinos).

La preferencia por el matrimonio endogámico fue superada, ahora los jóvenes tienen libertad de elegir parejas dentro o fuera de la comunidad.

\section{Anexo: Corpus de los relatos}

R2: El perro seductor. Relato de Apolonia Córdova, 50 años de edad, natural de San Antonio, Salcahuasi, Tayacaja, registrado en 1988.

Una muchacha criaba a un perro macho, al cual la quería mucho.

Cuando el perro maduró, la muchacha se "enredó" con él. El perro macho se transformaba en hombre, por las noches aparecía como joven que vestía con terno negro y corbata blanca. Este "muchacho", engañándolo, ingresaba por las noches a dormir con la muchacha.

La muchacha hizo para su amante un sujetador de bastas de pantalón, un delantal y una manta.

"Hazme esto y lo otro" -había pedido. 
"Hazme poner un delantal, anuda mis bastas, anuda una manta entre mi pecho y espalda - dijo-. Mañana asistiré a una invitación. Habrá un banquete en la pampa detrás de aquella loma. Allí vendrás, arreando las ovejas vendrás. Sacaré comida para ti” -dijo el muchacho.

"Bueno" -asintió la muchacha. Al día siguiente fue al lugar indicado por el novio. En la pampa ubicada detrás de la loma no había nada. Su hombre no aparecía. "Me habrá mentido. No hay nada" -iba pensando, cuando se percató que en la pampa había un grupo de perros que disputaban las carnes un burro muerto.

La muchacha se sentó viendo el espectáculo, y pudo ver que uno de los perros que disputaban la carne del burro estaba puesto con la manta que tejió para el novio. “¿Cómo hizo poner mi manta a ese perro? Cuando venga esta noche le romperé la cabeza” -pensó.

En verdad, cuando cayó la noche, el muchacho llegó apestando y portando la manta, luego dijo: “Por qué no has venido?”

"No estuviste. Allí sólo había perros que disputaban la carne de un burro”. Muy molesta dijo: “¿Por qué hiciste poner mi manta a ese perro? ¿Me hiciste tejer la manta para que lo use un perro?” Y luego golpeó furiosa con un palo al muchacho. Entonces el perro (el muchacho) saltó hacia fuera "Wikik, wikiw" -gritando.

La muchacha recién cobró juicio y dijo: "Con ese perro habré estado".

R3: Perro seductor. Relato de Olga M. H., de 18 años de edad, natural de San Juan de Yananaco, Salcabamba, Tayacaja, registrado en 1987.

Un perro, adoptando la forma de un muchacho, enamoraba a una chica. Cierto día el muchacho invitó a la muchacha a una fiesta. El muchacho adelantó y ella fue después.

Cuando llegó la mujer vio que había mucha gente y entre el gentío intentó ubicar a su novio “¿Dónde está?" -se preguntó. No logró ubicar a su enamorado. Pero vio que muchos perros se iban quitando a los huesos que las personas arrojaban. Entonces un perro empezó a poner huesos al lado de la muchacha, se trataba de un perrito bonito de color marrón claro.

La gente que iba observando empezó a reírse de la muchacha. Avergonzada regresó hacia su casa: "En vano me hizo ir. No me esperó" -pensaba furiosa. Entonces, el perro también se vino detrás de ella, y cuando llegaron a la casa de la mujer, el perro transformado en un hombre dijo: “¿Por qué te has venido?".

La muchacha respondió "Fui en vano. No estabas allí. Sólo había perros que disputaban los huesos. Cuando un perro empezó a traerme huesos me avergoncé y me vine".

"Ese era yo" -dijo el "muchacho". La muchacha meditando hizo hervir agua y dijo al muchacho: "Mira para allá" -luego le echó agua caliente. Entonces el muchacho salió de la casa dando alaridos de dolor y se convirtió en perro.

R4: Perro seductor. Relato de Lucía Reyes, 58 años de edad, La Loma, Salcahuasi, Tayacaja, registrado en 1988.

Cierta muchacha no conseguía varón e iba llevando sus ovejas hacia el cerro para ver si encontraba uno. Durante aquellas salidas se le presentó un joven elegante de quien se enamoró la muchacha. Entonces, cierta noche se quedaron a dormir por allí. Después el joven se fue y la muchacha también. El varón llegaba a la estancia sólo por las noches. Pero días después dice que el que llegó ya era un perro y se le pegó a la muchacha. Por la noche, el perro se transformaba en hombre. Así la muchacha apareció gestando y alumbró una criatura con cara de perro. Ese joven era por el día un perro blanco. Pero cierto día la muchacha siguió al perro y, oculta, observó que éste, cuando estaba jugando nomás, se transformaba en hombre. Después del descubrimiento, la muchacha dio muerte al perro que lo había engañado.

R6: Aqchi seductor. Relato de Albino Lazo Sollochuco, de 55 años de edad, natural de San Juan de Yananaco, Salcabamba, Tayacaja, registrado en 1987.

Una muchacha había ido a pastear sus ovejas al cerro. Entonces un joven le silbó. Éste tenía un saco 
negro y un pantalón blanco. Allí se habían enamorado.

Se querían e inclusive ya vivían juntos. Cierta vez, el muchacho dijo a la muchacha:

-"Cosecharé papas detrás de aquel cerro con diez peones" - diciendo se fue llevándose una manta wanka de la muchacha.

La muchacha preparó la comida y fue al lugar indicado y cuando dio la vuelta al cerro no encontró a nadie, sólo vio muchos aqchis que estaban escarbando las heces de las vacas.

Entonces vio a un aqchi que estaba usando su manta. "¿Cómo es posible que este muchacho haya dado mi manta al aqchi?" -pensando así retornó enfadada: "Por las puras traje comida, pude haber utilizado este tiempo en otra cosa" -pensando regresó.

Por la tarde, su compañero llegó muy molesto:

-“¿Por qué no me trajiste comida?”-Dijo a la muchacha.

Ella respondió:

-"Yo vine a la chacra que me indicaste y, como no encontré a nadie, regresé. Sólo vi que muchos aqchis estaban volteando a las heces y otra ave estaba utilizando mi manta".

El muchacho dijo:

-"Ese era yo".

R7 Aqchi seductor. Relato de Estela Ramón V. de 40 años de edad, natural de La Loma, Salcahuasi, Tayacaja, registrado en 1987.

Una muchacha vivía sola en su hatus (en su estancia) en la puna. Entonces un muchacho la sedujo. Éste vestía de terno negro, corbata blanca y botas rojas. Cierta noche, el joven dijo a la muchacha: "Mañana barbecharé un terreno para sembrar", dame una "delantera" (prenda blanca que cubre el pecho y los muslos para proteger la ropa del labrador) y unas "watanas" (cintas para anudar los bajos del pantalón a media pierna). La muchacha le dio las prendas que pidió el varón.

"Trabajaré en esa pampa" -diciendo la hizo ver una pampa lejana. "Mañana vendrás trayéndome la merienda, cocinarás tallarines porque me gustan mucho". Así, el hombre se fue a trabajar.

Al día siguiente, la muchacha hizo la merienda y fue al lugar donde estaba trabajando el joven. Sin embargo, cuando llegó no vio a su enamorado, sólo vio muchos aqchis que estaban volteando al excremento de las vacas. Entre esos aqchis vio a uno que estaba puesto con la delantera y las watanas las traía anudadas en las rodillas. Entonces la muchacha se indignó y dijo: "A ese lleqwe (asqueroso, inmundo) iba hacerle comer la merienda".

No obstante, el aqchi llegó por la noche muy molesto, con la intención de pegar a la chica porque no la hizo comer; sin embargo, la chica que se había dado cuenta del engaño le estaba esperando con un palo y cuando llegó la "molió" hasta darle muerte al pobre aqchi.

R8 Aqchi seductor. Relato de Gavino Mayta, Salcabamba, Tayacaja, registrado en 1988.

Una muchacha andaba pensativa de hombre. Iba al cerro a buscar a algún hombre como quien iba a pastar sus ovejas. Ya caminaba varios días así, sin encontrarse con ningún varón. El último día, cuando estaba pastando sus ovejas, llegó un joven mestizo con saco negro, con pantalón blanco (waruyuq) y con medias blancas. Éste la hizo anochecer a la chica conversándole. Cuando llegó la noche le dijo "vamos a mi casa, te puede pasar cualquier cosa a estas horas en el cerro" - diciendo se la llevó abandonando a sus ovejas. Así la hizo llegar a una hermosa casa y luego durmieron. Al día siguiente la mujer se despertó y se dio cuenta que dormía en una cueva ubicada al borde de un abismo. Con dificultad pudo bajar y regresar a su casa.

\section{R9 Aqchi seductor. Relato de Cristina Enciso Reginaldo, La Loma, Salcahuasi, Tayacaja, registrado en 1988.}

Eran dos muchachas jóvenes que vivían en su estancia cuidando a sus animales. Entonces se presentaron dos jóvenes pidiendo que les vendan unas ovejas. Las muchachas pensaron que se trataba de dos negociantes y se habían enamorado de ellos. "Quédense a dormir" -habían invitado las muchachas. Así los aqchis habían engañado a las muchachas. Habían dormido debajo de una inmensa roca. 
R11: Culebra seductora. Relato de Julia Ramos de 27 años de edad, natural de San Juan de Yananaco, Salcabamba, Tayacaja, registrado en 1987

Hubo una muchacha que cuidaba a sus ovejas en la estancia. A ésta se le presentó una culebra convertida en un joven. La muchacha conversaba con él. Siempre conversaban pasteando las ovejas. Un día la muchacha empezó a gestar y seguía viéndose con el hombre.

Llegó el día en que la muchacha debía alumbrar. Entonces, recién contó al joven que ella esperaba un bebé. Él dijo: "Iremos a tu casa. Yo viviré debajo de tu batán. Tú vendrás siempre".

La muchacha alumbró varias culebras. Después, cuando descubrió el batán vio que se trataba de una culebra. Dio gritos pidiendo auxilio. La culebra salió, entonces, varios hombres le dieron muerte junto a sus crías. La pobre muchacha gritaba: "No maten a mis hijos" -pero todo fue vano.

R12: Culebra seductora. Relato de Juliana Ramos Campos, de 37 años de edad, natural de San Juan de Yananaco, Salcabamba, Tayacaja, registrado en 1987.

Una muchacha vivía sola en su hatus (estancia), y por las noches, sólo por las noches, recibía la visita de un joven. La casa de la muchacha estaba en el poblado, bastante alejado de su hatus. Después de algunos meses, la muchacha apareció embarazada y contó al muchacho de su estado.

Cuando iba llegando los días en que alumbraría, la muchacha tuvo que trasladarse de su hatus a su casa; entonces, el muchacho le dijo: "Yo estaré viviendo debajo de tu maray (batán)".

Así, la muchacha alumbró varias culebras. Por eso contó a sus familiares que el "muchacho" le había dicho que estaría debajo del maray. Entonces, varios varones removieron el batán y allí encontraron una culebra inmensa, a la que dieron muerte entre todos; luego también exterminaron a todas las culebras pequeñas.

R13: Culebra seductora. Relato de Marcos Ramos, de 78 años de edad, Natural de Pongollo, Salcahuasi, Tayacaja, registrado en 1988.

Hubo una muchacha que no salía a ningún lado. A esta muchacha le gustaba mucho hacer los molidos en el batán. Pero debajo del batán vivía una culebra. Cuando la muchacha molía con las piernas abiertas, la culebra penetraba en la muchacha.

"Josecito" -diciendo le alimentaba con leche.

Cierto día, los padres de la muchacha se fueron a una fiesta. Entonces vinieron varios muchachos, “¿Por qué esta muchacha no sale? Nosotros la haremos salir” -habían dicho.

Cuando estuvieron viendo, la muchacha sacó leche en un mate y "José" -diciendo, la puso cerca al batán. Entonces salió una culebra enorme.

Entonces los muchachos dieron muerte a la culebra. Avisaron a sus padres y cuando éstos regresaron, su hija se había quitado la vida.

R14: Culebra seductora. Relato de Marcos Ramos, de 78 años de edad, natural de Pongollo, Salcahuasi, Tayacaja, registrado en 1988.

Cierta vez una muchacha cuidaba a sus animales en la estancia, lejos de sus padres. Ella cuidaba muchas vacas. Más allá de su choza había una gran roca. Para entonces la muchacha aún no había conversado con ningún muchacho. Vivía sola en la estancia. Entonces la culebra la había engañado haciéndose pasar por un joven. La muchacha ordeñando leche le ponía en un mate debajo de la gran roca. Así la culebra salía a alimentarse.

Por las noches, la culebra haciéndose pasar por un joven dormía con la muchacha. Entonces la gente que los vio avisó a la madre de la muchacha. La madre dijo:

-Cómo va aparecer mi hija gestando -diciendo mandó al esposo.

Su padre se fue a la estancia antes de que amaneciera, encontrado a la muchacha cuando estaba cocinando y le preguntó:

-¿De quién estás gestando?

-Mi esposo está durmiendo en la cama -respondió la muchacha. 
Cuando el padre asomó al interior de la choza, una gran culebra estaba enroscada dentro de la cama. -¿Estuviste con una culebra? -Preguntó a la muchacha.

Con un palo dio muerte al bicho. Entonces la muchacha de rabia se mató. Muchas culebras pequeñas salieron del vientre de la muchacha. El padre logró dar muerte a algunas y otras lograron escapar. Desde entonces quedaron las culebras.

R18: “Gentil seductor: Relato de Cristina Enciso Reginaldo, La Loma, Salcahuasi, Tayacaja, registrado en 1988.

Había dos muchachas que estaban en su estancia. Allí iban dos "gentiles" a engañar a las muchachas, pero iban sólo por las noches. Las chicas se preguntaban "¿por qué vienen sólo por las noches?".

"Lo haremos amanecer bailando. Debieran venir en el día, por lo menos trayendo un poco de leña y viendo a nuestras ovejas" - dijeron las chicas. Cuando los muchachos llegaron una noche, las muchachas dijeron que harían Santiago (fiesta) y bailaron con ellos toda la noche.

Cuando el gallo cantó hasta dos veces, "por favor, déjenos ir ya"-dijeron los muchachos. "Sino diremos ¡Tuqruruq!". Como las muchachas no las soltaron, cuando amaneció, los muchachos, que eran unos esqueletos, se derrumbaron ¡Tuqruruq! -diciendo. Las muchachas indignadas por el engaño arrojaron los huesos y a algunos los quemaron.

\section{Bibliografía}

ALCEDO, Antonio (de). Diccionario geográfico-histórico de las Indias occidentales ó América, T. V, Imprenta de Manuel González, Madrid, 1789.

ARRIAGA (DE), Pablo Iofeph. Extirpacion de la idolatría del Pirv. Dirigido al Rey N. S. en su Real Consejo de Indias, Geronymo de Contreras Impreffor de libros, Lima, 1621.

ÁVILA, Francisco (de). Dioses y hombres de Huarochirí, (traducción de José María Arguedas), Siglo Veintiuno Editores, México, 1975.

ARANGO, Juanita. "La deidad protectora de la agricultura" en Boletín Museo del Oro 53, enero junio de 2005, Bogotá, 2005, págs. 50-73.

ARGUEDAS, José María. Canciones y cuentos del pueblo quechua, Huascarán, Lima, 1949.

ARGUEDAS, José María. "Yawar fiesta” en Obras completas, T. II, Horizontes, Lima, 1983, págs. 69-227.

ARGUEDAS, José María. Cantos y cuentos quechuas, Munilibro 12, MML, Lima, 1986.

ARGUEDAS, José María y Francisco IZQUIERDO. Mito, leyendas y cuetos peruano, Punto de Lectura, Santillana, Lima, 2012.

BÁEZ-JORGE, Félix. Las voces del agua. El simbolismo de las sirenas y las mitologías americanas, Universidad Veracruzana, Colección Biblioteca, México, 1992.

BENDEZÚ, Edmundo. Literatura quechua, Fundación Biblioteca de Ayacucho, Caracas, 1993.

BIBLIOTECA DIGITAL ANDINA. Tradiciones orales de Huancavelica. Relatos del primer concurso de recopilación de tradiciones orales, BNP, Lima, 2002.

CÁCERES, Adolfo. Narrativa quechua del Tawantinsuyo, Selección y prólogo de ACR, Biblioteca de Cultura Popular, Ediciones El Sol, Buenos Aires, 2006.

CÁCERES, Efraín.El juicio del agua - "unu huisu”: Simbolismo y significado ecológico del agua en los mitos andinos. El milagro de la laguna salda de Musuq Llaqta, Abya Yala/CICTA, Quito, 2002.

CASTRO POZO, Hildebrando. Nuestra comunidad indígena, Perugraph Editores, Lima, 1979.

CIEZA DE LEÓN, Pedro. La crónica del Perú, PEISA, Lima, 1973.

CHEVALIER, Jean y Alain GHEERBRANT. Diccionario de los símbolos, Herder, Barcelona, 1986.

FLORES OCHOA, Jorge A. "Enqa, Enqaychu illa y Khuya Rumi: Aspectos mágico-religiosos entre pastores" in Journal de la Sociétédes Américanistes, Tome 63, 1974, págs. 245-262.

FUENZALIDA, Fernando. "Santiago y el Wamani: Aspectos de un culto pagano en Moya" en Debates en Sociología; N$^{\circ}$ 5, PUCP, Lima, 1980, págs. 155-187.

GARCILASO DE LA VEGA, Inca. Comentarios reales de los incas, tomo I, CBP N ${ }^{\circ} 15$, PEISA, Lima, 1973a.

GARCILASO DE LA VEGA, Inca. Comentarios reales de los incas, tomo II, CBP N 19 , PEISA, 
Lima, 1973b.

GOEPFERT, Nicolás. "Ofrendas y sacrificio de animales en la cultura Mochica: El ejemplo de la Plataforma Uhle, Complejo Arqueológico Huacas del Sol y de la Luna" en Arqueología Mochica, nuevos enfoques. Actas del Primer Congreso Internacional de Jóvenes Investigadores de la Cultura Mochica, L. Castillo y otros (eds.), IFEA, FE-PUCP, Lima, 2008, pág. 231-244.

GUAMAN POMA DE AYALA, Phelipe. Nueva coronica y buen gobierno, T. 1, Biblioteca Ayacucho, Caracas, 1988.

HUARCA, Jeison. "El dulce encanto de la perdiz" en Concurso de cuentos. El futuro en nuestras manos, Fundación Mapfre, s/f. Disponible en https://elfuturoennuestrasmanos.fundacionmapfre.org/es/cuento-primera-edicion/8304/el-dulce-encanto-de-la-perdiz/.

KULAK, Ewa . Delfín rosado de Amazonas, Colombia, 2006. Disponible en http://www.ewakulak. com/index.php?option=com_content\&task=view\&id=413\&Itemid=205.

LANDEO, Pablo. Categorías andinas para una aproximación al willakuy, ANR, Lima, 2014.

LÉVI-STRAUSS, Claude. Mitológicas 2: De la miel a las cenizas, FCE, México, 1972.

LÉVI-STRAUSS, Claude. Mitológicas 1: Lo crudo y lo cocido, FCE, México, 2002.

LÉVI-STRAUSS, Claude. Antropología estructura. Mito, sociedad y humanidades, Siglo Veintiuno Editores, México, 2004.

LIRA, Jorge A.Cuentos del Alto Urubamda, CERA - Bartolomé de las Casas, Cusco, 1990.

MILLONES, Luis y Hiroyasu TOMOEDA. "Las sirenas de Sarhua" en Letras, Año LXXV, 107-108, UNMSM, Lima, 2004, págs. 15-31.

MILLONES, Luis. “El bestiario del manuscrito de Huarochirí” en Diálogo Andino N³6, Departamento de Ciencias Históricas y Geográficas, Facultad de Educación y Humanidades, Universidad de Tarapacá, Arica, 2010, págs. 7-14.

MOROTE BEST, Efraín. Aldeas sumergidas, CBC, Cusco, 1988.

MOYA, Ruth y Fausto JARA. Taruka la venada: literatura oral kichwa”, Ministerio de Educación de Ecuador, Quito, 2008.

NAVARRO DEL ÁGUILA, Víctor. Las tribus de Ancku Walokc, Atusparia, Lima, 1983.

NIEVES, Fabián. Narraciones andinas. Huánuco, Rikchary, Huánuco, 1991.

ORTIZ, Alejandro. Sobre el tema de la pasión. Mitología andino-amazónica, FE-PUCP, Lima, 2004.

PLASENCIA SOTO, Rommel . "Julián Ayuque: Narratividad y conflicto cultural" en Investigaciones Sociales, Vol. 16, №29, UNMSM-IIHS, LIMA, 2012, págs. 65-74.

SAAVEDRA MUÑOZ, Néstor . Alrededor de la tradición oral andina. Una lectura del cuento "La amante del cóndor", 2011. Disponible en http://laordendelosquintin.blogspot. com/2011/12/alrededor-de-la-tradicion-oral-andina.html.

SÁNCHEZ, Rodolfo. "Simbolismo y ritualidad en torno a la papa en los Andes" en Investigaciones Sociales, Vol.15, N²7, UNMSM/IIHS, Lima, 2011, págs.15-42.

SARMIENTO DE GAMBOA, Pedro. Historia de los Incas, Miraguano \& Polifemo, Madrid, 1988.

TACCA, Lorenzo. "La serpiente en los Andes Prehispánicos (imágenes en el valle de Arequipa)" en Revista de Historia, EPH, UNSAA, Arequipa, 2012, págs. 15-19.

TAIPE, Néstor. "La sustitución en los ritos de sacrificio" en Gazeta de Antropología No 21-2005, Texto 21-06, Grupo de Investigación Antropología y Filosofía - Departamento de Filosofía - Universidad de Granada, España, 2005.

TAIPE, Néstor y ORREGO Rita. "El sol, la luna y las estrellas" en La Gaceta, Boletín Informativo № 5, Año VI, Set. 1996 - marzo 1997, CPCF, Huancayo, 1997a, pág. 10.

TAIPE, Néstor y ORREGO Rita. "Laboriosidad y ociosidad en dos relatos andinos" en Allpanchis $\mathrm{N}^{\circ}$ 48, IPA, Año XXVIII, Cusco, 1997b, págs. 175-188.

TAYLOR, Gerald. "Juan Puma, el hijo del oso: Cuento quechua de la Jalca, Chachapoyas" en $\mathrm{Bu}$ lletin de l'Institut Français d'Études Andines, $N^{\circ}$ spécial: “Tradición oral y mitología andinas", Tomo 26, №3, Lima, 1997.

TAYLOR, Gerald. Ritos y tradiciones de Huarochirí, IEP/IFEA/FE - UNMSM, Lima, 2008.

VALDERRAMA, Ricardo y Carmen ESCALANTE. "Agua, riego, alianza y competencia en mitos del Cusco" en Desde afuera y desde adentro. Ensayos de etnografía e h historia del Cusco y Apurímac, Luis Millones (ed.), Senri Ethnological Reports 18, Osaka, 2000, págs. 261294. 
WONG, Antonio. “Los fundamentos amazónicos en la antigua religión prehispánica. Los murciélagos en el simbolismo de los Chavín" en Investigaciones Sociales, Vol. 13, N²2, UNMSM/IIHS, Lima, 2009, págs. 239-245.

WONG, Antonio y Luz ARBAIZA. "La mitología amazónica y su relación con la simbología Chavín” en Investigaciones Sociales, Vol.14, N²4, UNMSM/IIHS, Lima, 2010, págs. 341350.

WEBER, David. Juan El Oso, Serie Lingüística Peruana, N²6, ILV, Pucallpa, 1987.

\section{$\operatorname{coc}$}

